\title{
Table 2
}

Arthur H. Rubenstein: leadership roles

Chairman of Medicine, University of Chicago, 1981-1997

Dean, Mount Sinai School of Medicine, 1997-2001

Dean/Executive Vice President of the Health System, University of Pennsylvania, 2001-2011

President, Association of American Physicians

Chairman, American Board of Internal Medicine

President, Association of Professors of Medicine

Chair, Association of Academic Health Centers

President, Central Society for Clinical Research

believe that much of his success is rooted in his close-knit family bonds. In closing, I would like to thank the AAP for providing me the opportunity to tell you about my mentor, friend, and colleague, Arthur Rubenstein. I can think of no one more deserving of this prestigious award and congratulate the AAP on their wise selection. Thank you.
1. Robbins DC, Tager HS, Rubenstein AH. Biologic and clinical importance of proinsulin. NEnglJ Med. 1984;310(18):1165-1175.

2. Steiner DF, Rubenstein AH. Recent studies on the biosynthesis, secretion and metabolism of proinsulin and C-peptide. In: Musacchia XJ, Breitenbach RP, eds. Proceedings of the 8 th Midwest Conference on Endocrinology and Metabolism. Columbia, Missouri, USA: University of Missouri Press, 1973:43-59.

3. Block MB, Rosenfield RL, Mako ME, Steiner DF, Rubenstein AH. Sequential changes in betacell function in insulin-treated diabetic patients assessed by C-peptide immunoreactivity. $N$ Engl J Med. 1973;288(22):1144-1148.

4. Polonsky KS, et al. Use of biosynthetic human $\mathrm{C}$-peptide in the measurement of insulin secretion rates in normal volunteers and type I diabetic patients. J Clin Invest. 1986;77(1):98-105.

5. Polonsky KS, et al. Abnormal patterns of insulin secretion in non-insulin-dependent diabetes mellitus. New Engl J Med. 1988;318(19):1231-1239.

\section{Acceptance of the 2012 Association of American Physicians George M. Kober Medal A fortunate life in academic medicine}

\author{
Arthur H. Rubenstein
}

G ood morning everybody. And thank you, David, for this great honor, and to the councilors and leadership of the Association of American Physicians, and, of course, to all of you for coming here today. I do wish to express my deepest appreciation to the AAP for honoring me with the Kober Medal, which has been awarded to me today. This is a great honor that I feel very humble to receive. I particularly wish to thank my close friend and colleague, Dr. Kenneth Polonsky, for his beautiful presentation today and for his continuous support for more than 30 years. He and his wife, Lydia, and his family have been like an extended family to Denise and me, and to our children as well, since he became my fellow in the late 1970s. Now that Dr. Larry Jameson has succeeded me, I actually had the luxury of time to think, and I've considered the factors that have influenced my career and brought me to this very special

This article is adapted from a presentation at the ASCI/ AAP Joint Meeting, April 29, 2012, in Chicago, Illinois, USA.

Conflict of interest: The author has declared that no conflict of interest exists.

Address correspondence to: Arthur H. Rubenstein, University of Pennsylvania Perelman School of Medicine, TRC 12th Floor, Room 12-122, 3400 Civic Center Boulevard, Building 421, Philadelphia, Pennsylvania 19104-5160, USA. Phone: 215.746.8587; Fax: 215.573.9138. E-mail: ahrdean@mail.med.upenn.edu.

Citation for this article: J Clin Invest. 2012; 122(11):4288-4292. doi:10.1172/JC66850. day. I think there are three main factors (Table 1). The first is family, as Kenneth has so rightly pointed out. The second is mentors and a network of colleagues. And thirdly, is being in the right place, at the right time, and with the right people. Of course, all of that had nothing to do with me, so you have to have good luck and fortune in your life, and I've been abundantly showered with that.

Let me begin with my family (Figure 1). My father was a refugee from Poland after the First World War and became a pharmacist, as he did not have the money or resources to become a physician, which was his first love. When I decided to become an accountant after graduating from high school, he took me aside and said quietly, "I think it would be better, Arthur, if you became a physician.” And

\section{Table 1}

Key elements in shaping the author's career

Family

Mentors and network of colleagues

Good fortune:

Right place

Right time

Right people because of my enormous respect for him, I said, "That's a good idea, Dad," and then I enrolled in medical school. My mother was a remarkable role model; a generous, kind, warm-hearted woman who always did the right thing. Both my father and mother's influence on my sister, brother, and myself, and many other family members, was indelible. Denise, my wife of nearly 50 years (Figure 2), was actually my resident at the University of Witwatersrand Hospital. I was her intern and, after trying and failing to best her in terms of clinical acumen and basic knowledge on ward rounds, I decided that I better just ask her to marry me.

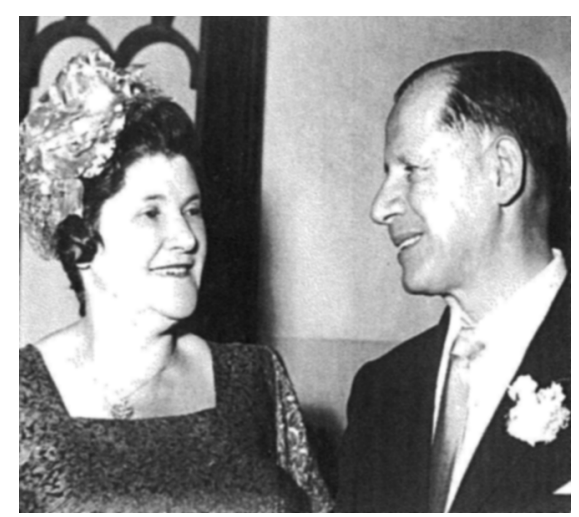

Figure 1

The author's mother and father. 


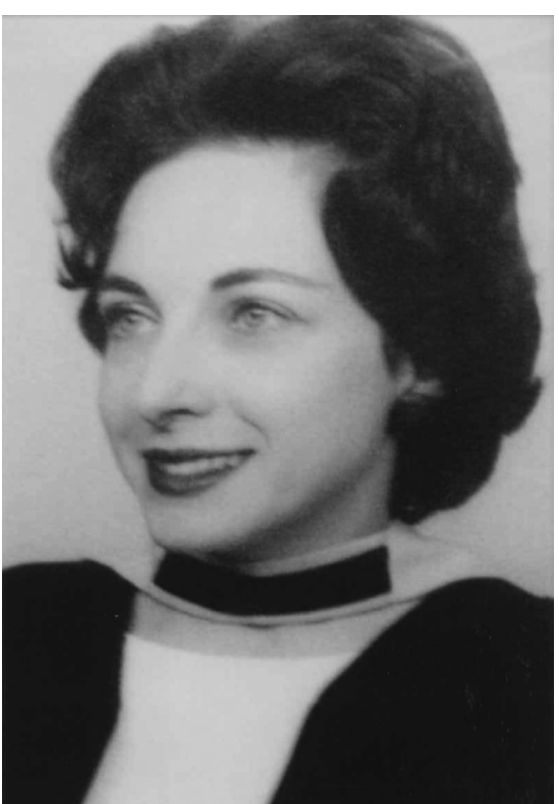

Figure 2

The author's wife, Denise Rubenstein.

Over the past nearly half a century, she has made at least 10 major decisions for our family, all of which turned out to be correct, and in which my initial choice would have been wrong. She overrode these with her usual grace, and, of course, it turned out that every time, everything worked out well. She has been the centerpiece of our family and my career, and I would have gone nowhere without her. Maybe I'll just ask her to stand. She'll hate me for it, but there we are - after 49 and a half years divorce is not an option, so I took the chance.

Figure 3 shows my family: two sons, Jeffery and Errol; my daughter-in-law, Michaela; and four beautiful grandchil-

\section{Table 2}

The author's mentors

Guy Elliott

Russell Fraser

Godfrey Getz

Murray Rabinowitz

Donald Steiner

Richard Landau

Alvin Tarlov

Jack Rowe

Judith Rodin

Amy Gutmann

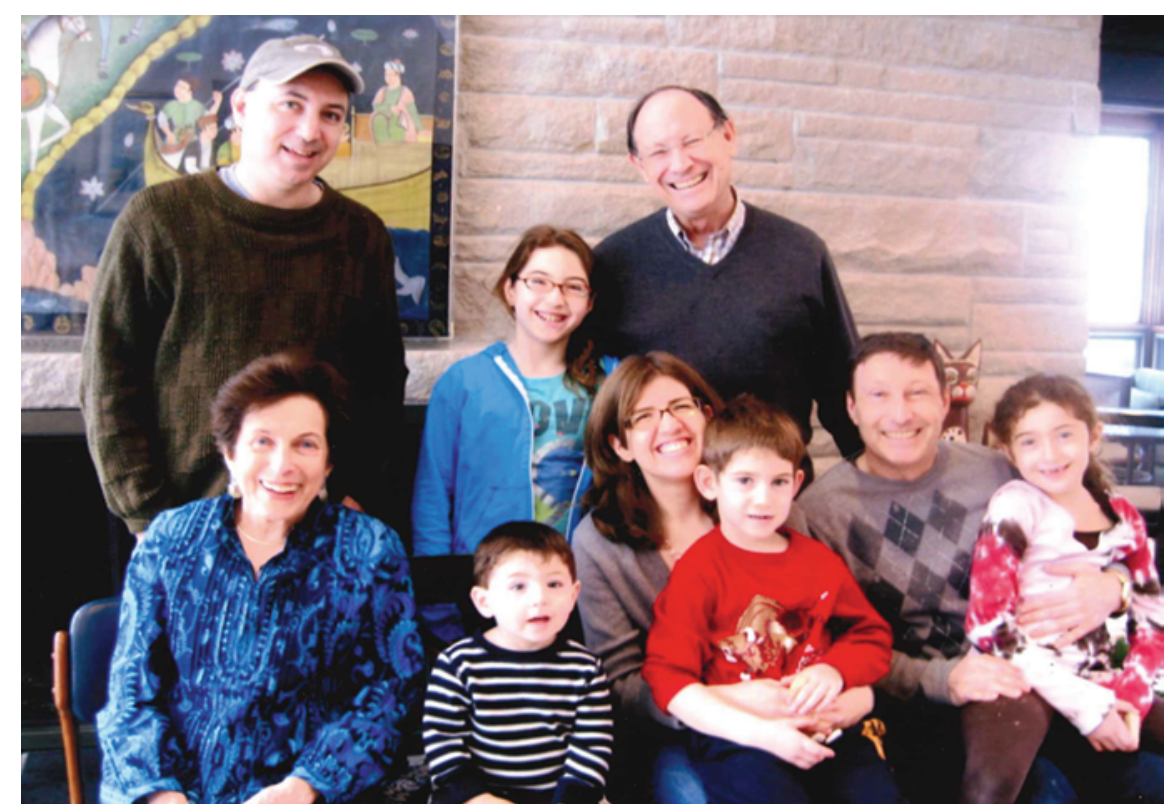

Figure 3

The author's family. dren, Ayelet, Maya, Adam, and Noah. Jeffery is the Skirball Professor of Talmud and Rabbinic Literature at NYU, and Michaela is an endocrinologist at Columbia. Errol, after more than 12 years of a very serious illness and many hospitalizations, showed enormous courage and determination, completed his college education, and then, remarkably, like a miracle, earned a master's degree and now teaches in the New Jersey Community College System. Jeffery and Errol are truly remarkable individuals, whom I respect and love very much. I would also mention my sister-in-law, Dr. Maureen Hack, who is here today. She is a Professor of Pediatrics at UH Rainbow Babies and Children's Hospital at Case Western Reserve, and I feel very blessed that she was able to join us today.

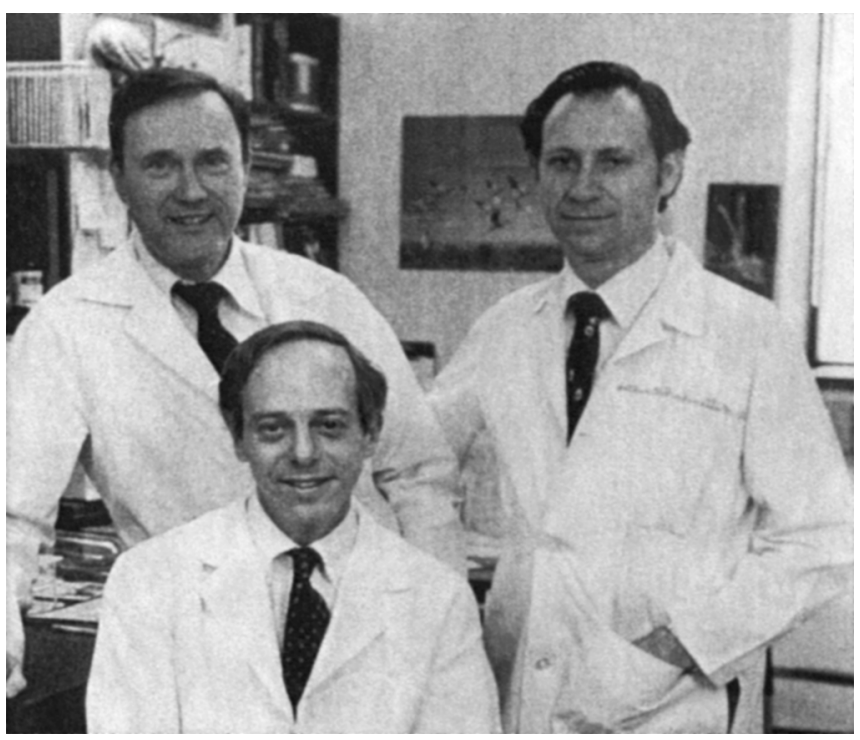

Figure 4

Donald Steiner, Howard Tager, and the author. 


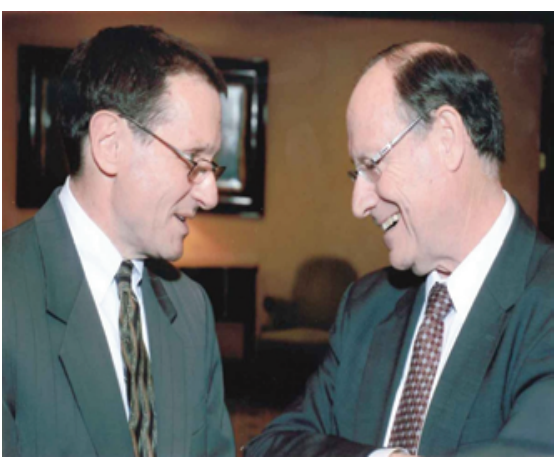

Figure 5

Kenneth Polonsky and the author.

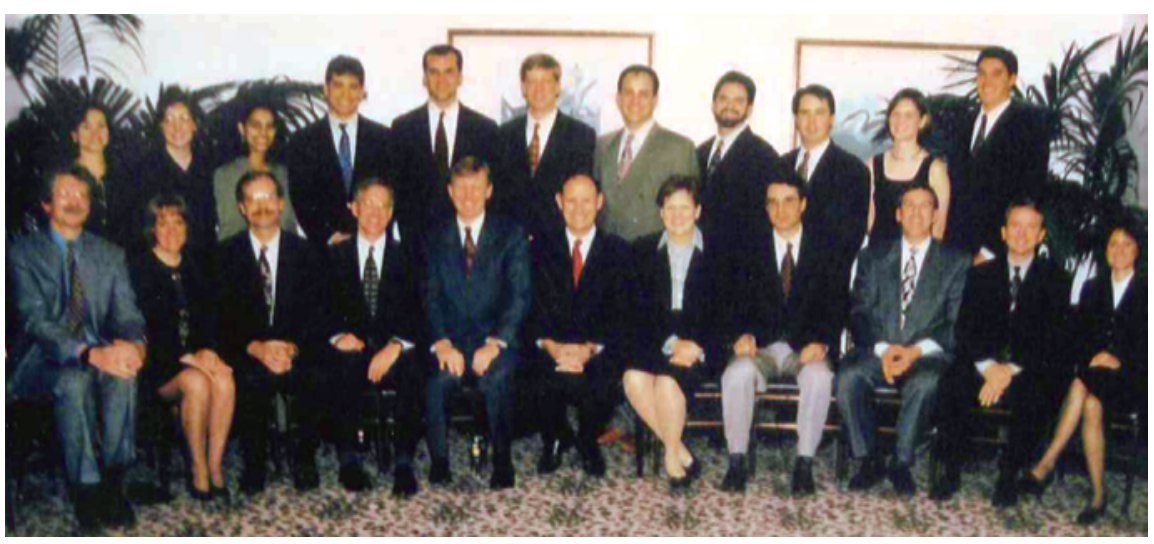

Figure 6

University of Chicago Department of Medicine Chief Residents, 1981-1997.
I have also been extremely fortunate to have had the benefit of outstanding mentors (Table 2). Time, unfortunately, does not permit a full description of their influence in shaping my career, and it's not even possible to mention all of them and their contributions. In brief, Dr. Godfrey Getz initiated my scientific training in South Africa, and he was instrumental in bringing Denise and me to the United States in 1967. The late Murray Rabinowitz was a remarkable mentor who persuaded a reluctant endocrinologist that there was value in studying the molecular biology of yeast mitochondria. That was quite a step for me, but there I was, growing big batches of yeast in various concentrations of oxygen. Don Steiner taught me to be a rigorous scientist, and he was incredibly generous to share his great scientific discovery on the biosynthesis of insulin with me, as Kenneth has outlined (Figure 4). He was also generous with many other colleagues and subsequently guided my career for more than 30 years. I owe an indelible debt to him. Richard Landau was the Chief of the Section of Endocrinology, who offered me my first faculty position. At the time, I was very naïve as a newly arrived postdoctoral fellow from South Africa. I remember well my first interview

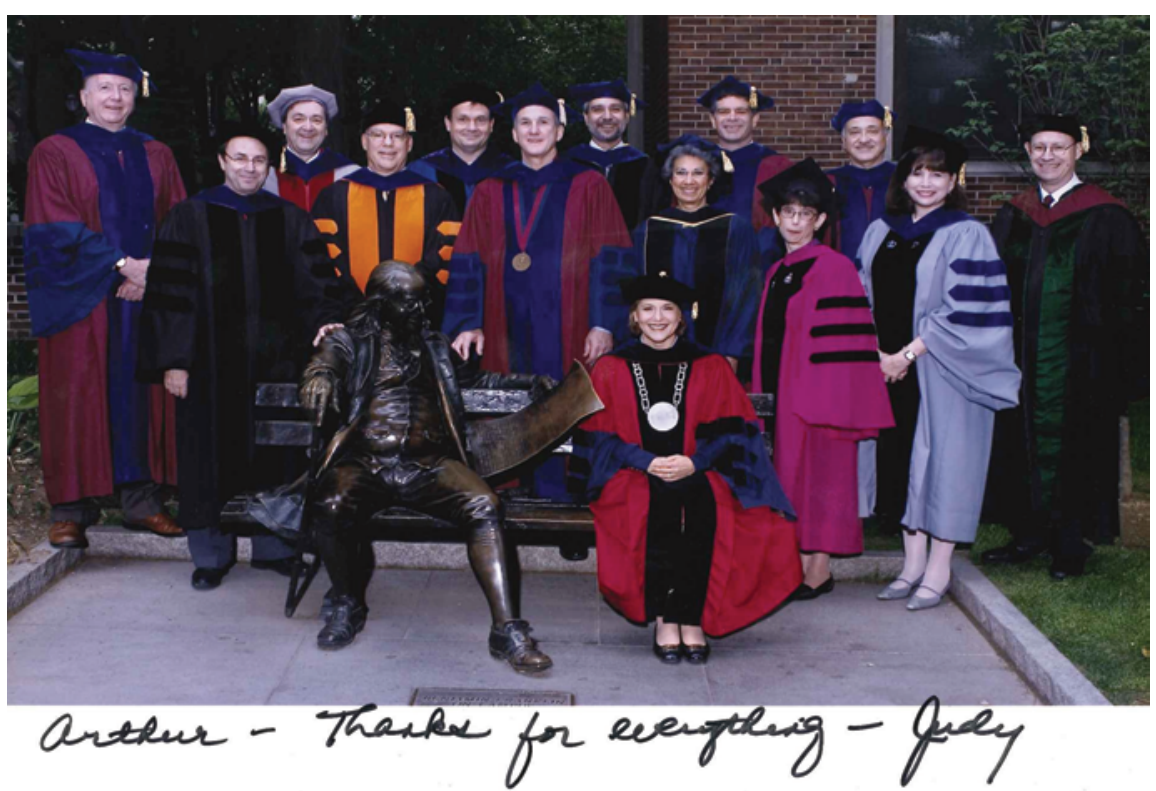

Figure 7

Judith Rodin.

with him about a faculty position. He said, "Would you like to be an assistant professor?” I said, "Gee, that sounds like a good idea; I'd love to be one." And then he looked at me pityingly and said, "Do you want to know your salary?" I said, "Sure, that sounds like a good idea. What would it be?” He said, “\$11,000.” I said, “Thank you." He said, "You really are a chump. You know, in this country, you're supposed to negotiate your salary." So I said, "Well, how do you do that?" He said, "Ask for more.” I said, "Well, \$12,000.” He said, "No, the minimum is 15 ." I said, "15." He said, "I'll give you 16." I remember that like yesterday.

Ken Polonsky (Figure 5), who I recruited to be my fellow, very soon became more accomplished than myself, and I view him now as being amongst my great role models. His leadership roles at Washington University, and now at the University of Chicago, have been marked by great success, and I am so proud of him. Al Tarlov, the Chair of the Department of Medicine, offered me the position of Vice Chair; and when the Medical School failed to recruit an external candidate - they interviewed six of them - they turned to me and said, "Would you like to be the Chair?" And I said, "Sure." And that was 1981. It didn't matter that I was the fallback candidate. I was so happy to get that position. My 15 years as the Chair of the Department of Medicine, and in partnership with Dr. Leif Sorensen, the Associate Chairman, were exhilarating. Figure 6 shows the Chief Residents with whom I worked, and Dr. Holly Humphrey, who is my close colleague, advisor, and program director. Together we recruited an outstanding 


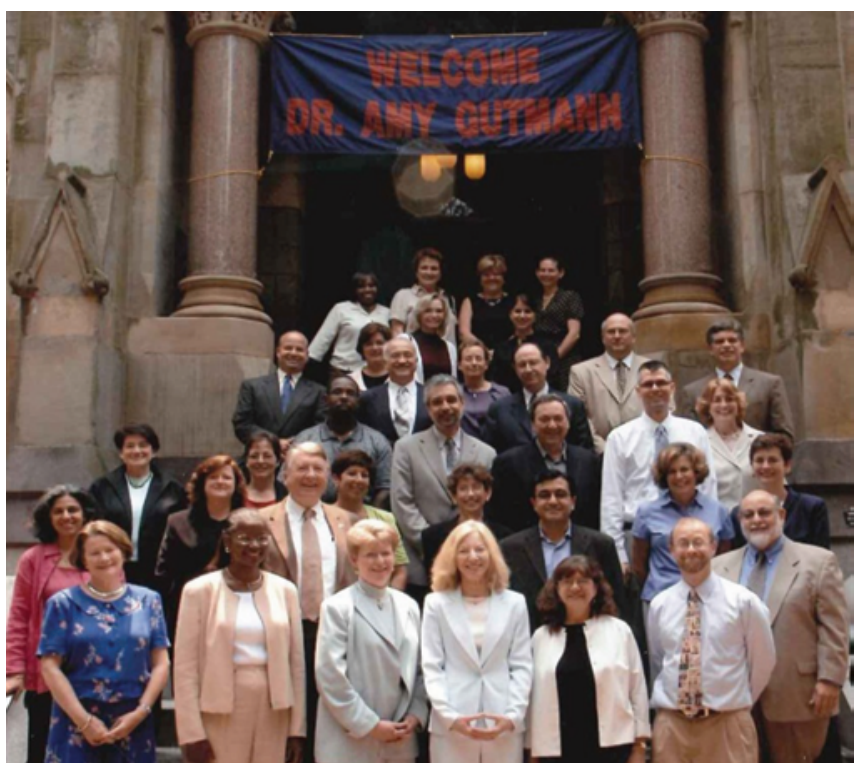

Figure 8

University of Pennsylvania Perelman School of Medicine President Amy Gutmann.

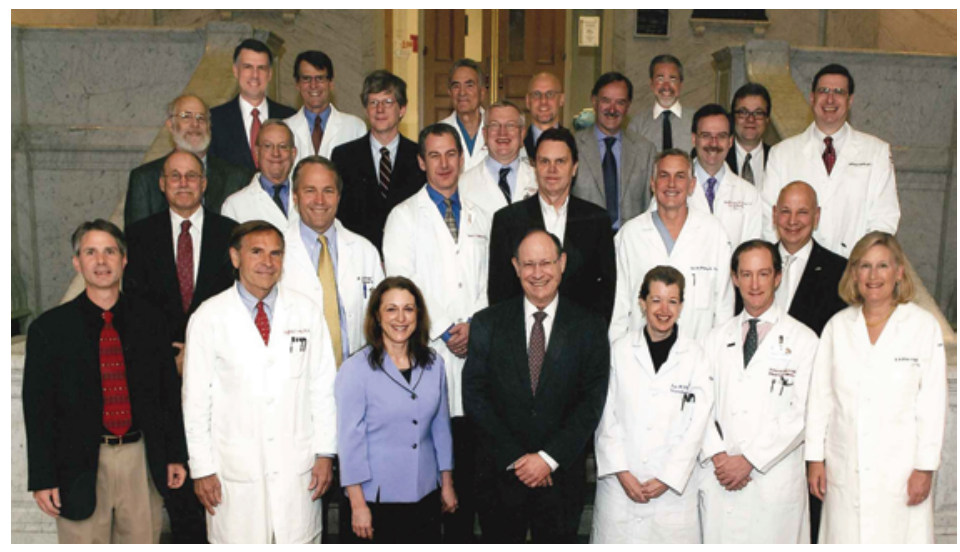

Figure 9

University of Pennsylvania Perelman School of Medicine Department Chairs.

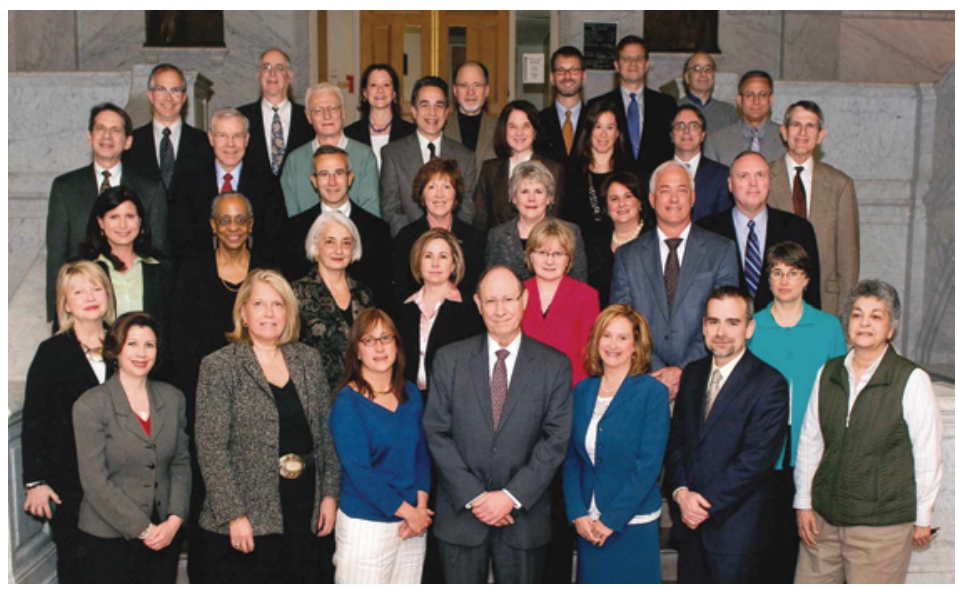

Figure 10

University of Pennsylvania Perelman School of Medicine 2010-2011 Dean's staff. group of Section Chiefs and developed a wonderful department with a special balance of education, research, and patient care, which I valued so much.

After four years as Dean of the Mount Sinai School of Medicine, Dr. Michael Brown, who is a close friend, a Penn graduate, and a Nobel Laureate, suggested my name to the University of Pennsylvania School of Medicine Search Committee, which was searching for a successor to Dr. William Kelley, a previous Kober Medal winner. President Judith Rodin (Figure 7) was very persuasive in attracting me to Penn, where the last 10 years as Dean and Executive Vice President for the Health System has been an incredible experience. I also want to say that my successor, Dr. Larry Jameson, who will be the President of this organization in two years, has in the last year continued to build upon what we did at Penn and I'm so proud that he has followed me in this position. Dr. Rodin was followed by President Amy Gutmann (Figure 8), who is an accomplished leader of the university and is very supportive of the School of Medicine and Health System. I've worked for two outstanding presidents, and it has been an absolute pleasure to work with these wonderful leaders.

We assembled a remarkable group of Chairs (Figure 9) and a dedicated and committed administrative group (Figure 10) to support faculty and students. Together with Ralph Muller, who I recruited to be the CEO of the Health System from the University of Chicago, we focused on building a patient-centered culture to compliment the outstanding education and research programs that Dr. William Kelley had established. Together we stabilized the budget, built an attractive outpatient facility, and a new translation research building (Figure 10); and I might tell you a brief anecdote about that. I have always believed that trying to put things together so that people can collaborate and communicate with each other - of course I have trouble with Facebook and all those other social media ways of doing so - was the right way to build a cohesive organization. We had a site about three or four blocks away from the outpatient building where we could have built a research building. But, I really worried that the distance between clinical work and research would be a hindrance to true translational medicine and collaboration. So one day we were sitting 


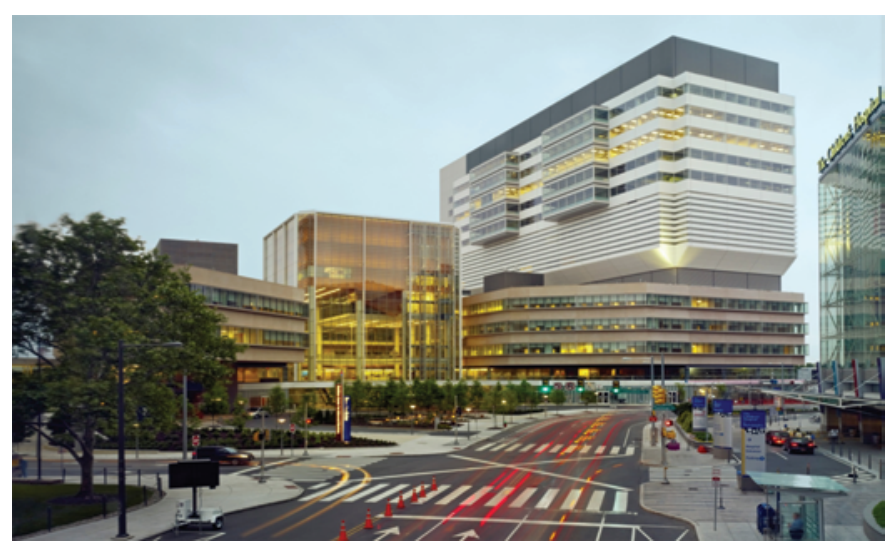

Figure 11

University of Pennsylvania Perelman Center for Advanced Medicine.

around thinking about how we could deal with this and one of our colleagues, Kevin Mahoney, said, "Well, why don't you just build a translation research building on top of the outpatient building?" And I said, "That's ridiculous." And then we did it and, of course, it turned out to be an enormous success (Figure 11).
These successes allowed us to recruit outstanding faculty and students, and build wonderful interdisciplinary research programs that Kenneth outlined for you. Arriving from South Africa 44 years ago as a postdoctoral fellow from a foreign country, and envisioning a career such as I've had, was completely inconceivable. It is a tribute to the generous spirit of this country that encourages everyone to do their best, irrespective of their country of origin or where they did their training, as well as to all the wonderful people whom I have mentioned and many others whom time does not permit me to discuss. But I do want to express my appreciation and gratitude to all of them.

In conclusion, I do feel very fortunate to receive this wonderful award, which I will value forever, and I thank all of you for this very great honor. 